\title{
Chemokine (C-C Motif) Ligand 21 Measurement
}

National Cancer Institute

\section{Source}

National Cancer Institute. Chemokine (C-C Motif) Ligand 21 Measurement. NCI

Thesaurus. Code C147315.

The determination of the amount of chemokine (C-C motif) ligand 21 present in a sample. 